\title{
FEMINISM AND TRADITION IN AESTHETICS
}

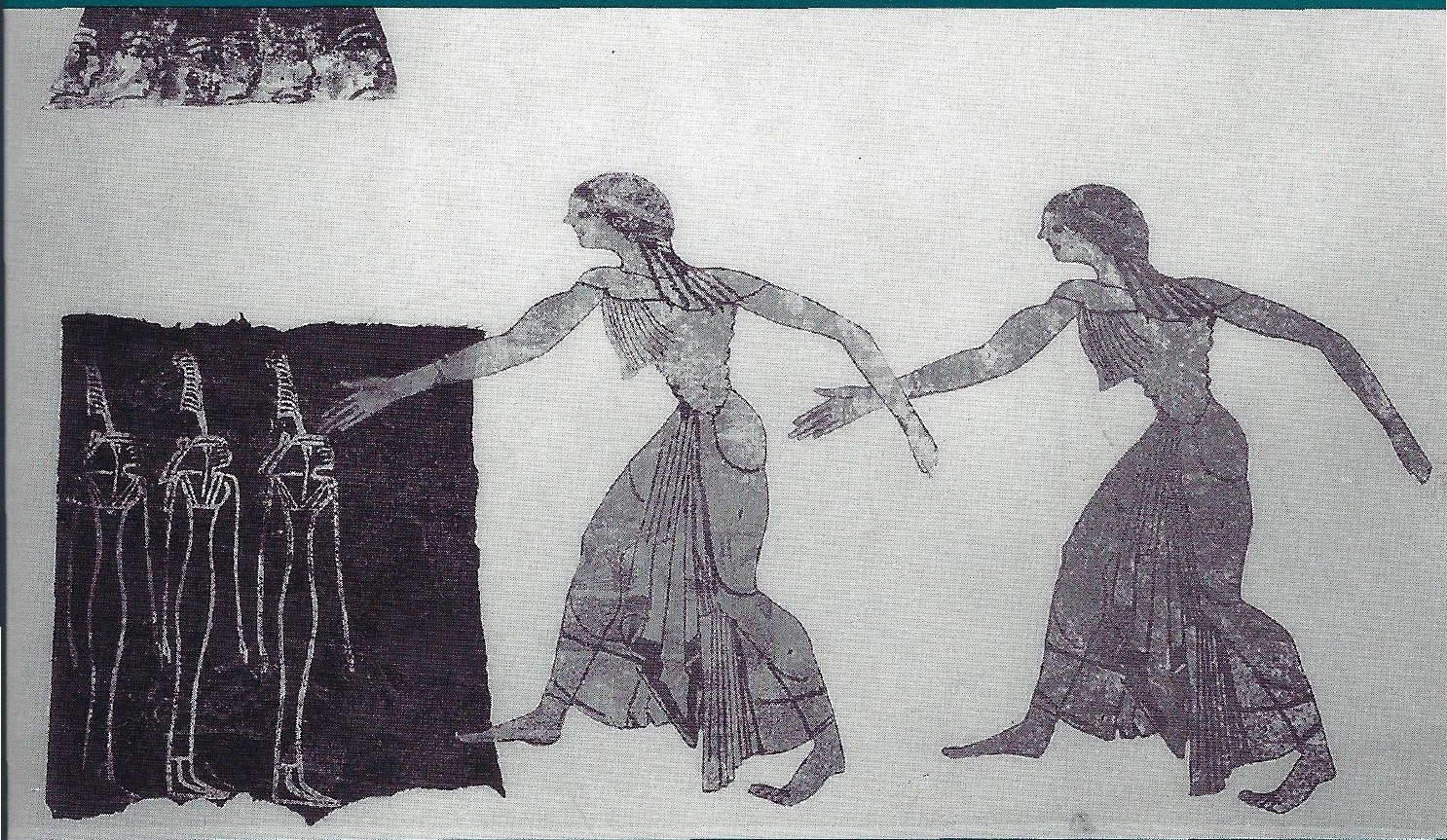

E D I T E D B $\quad$ B Y

PEGGY ZEGLIN BRAND AND CAROLYN KORSMEYER 


\title{
FEMINISM AND
}

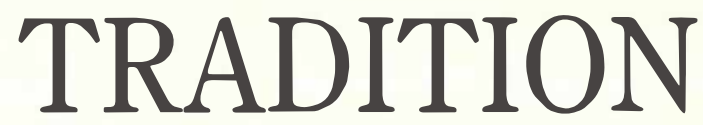
IN

\section{AESTHETICS}

\author{
EDITED BY \\ Peggy Zeglin BRAnd \\ AND \\ CAROLYN KorSMEyer
}

The Pennsylvania State University Press

University Park, Pennsylvania 
Library of Congress Cataloging-in-Publication Data

Feminism and tradition in aesthetics / edited by Peggy Zeglin Brand and Carolyn Korsmeyer.

p. $\quad \mathrm{cm}$.

Includes bibliographical references ( $\mathrm{p} . \quad$ ) and index.

ISBN 0-271-01340-0 (cloth : acid-free paper) -

ISBN 0-271-01341-9 (paper : acid-free paper)

1. Aesthetics. 2. Feminist theory. 3. Feminism and the arts.

I. Brand, Peg. II. Korsmeyer, Carolyn.

HQ1219.F45 1995

$305.42-\mathrm{dc} 20$

Copyright @ 1995 The Pennsylvania State University

Chapters $1,3,5,7,9,12,15,16,17,18$, and 20 were previously published as a special issue of the Journal of Aesthetics and Art Criticism, Vol. 48, No. 4 (Fall 1990), copyright 1990 by The American Society for Aesthetics, and are reproduced here by permission of the Society.

All rights reserved

Printed in the United States of America

Published by The Pennsylvania State University Press, University Park, PA 16802-1003

It is the policy of The Pennsylvania State University Press to use acid-free paper for the first printing of all clothbound books. Publications on uncoated stock satisfy the minimum requirements of American National Standard for Information SciencesPermanence of Paper for Printed Library Materials, ANSI Z39.48-1984. 


\section{Contents}

Iist of Tllustrations

Arthur C. Danto

xvii

Intevduction: Aesthetics and Its Traditions

Peggy Zeglin Brand and Carolyn Korsmeyer

1 Gender and Eighteenth-Century Aesthetic Theory: New Readings of Traditional Theories of Taste, Beauty, and Sublimity

1 Beautiful and Sublime: "Gender Totemism" in the Constitution of Art Paul Mattick, Jr.

2 Gendered Concepts and Hume's Standard of Taste

Carolyn Korsmeyer

3 Intensity and Its Audiences: Toward a Feminist Perspective on the Kantian Sublime

Timothy Gould

4 Stages on Kant's Way: Aesthetics, Morality, and the Gendered Sublime

Christine Battersby 

II Aesthetic Responses: Subjective Differences and the Challenge to Traditional Theories of Appreciation

5 Oppressive Texts, Resisting Readers, and the Gendered Spectator: The "New" Aesthetics Mary Devereaux

6 The Oppositional Gaze: Black Female Spectators bell hooks

7 A History of Music Renée Lorraine

\section{Feminist Art and the Refusal of Aesthetic Value}

8 "Who Is Speaking?" Of Nation, Community, and FirstPerson Interviews

Trinh T. Minh-ha

9 Interweaving Feminist Frameworks

Elizabeth Ann Dobie

10 Monologues from "Four Intruders Plus Alarm Systems" and "Safe"

Adrian Piper

11 Revising the Aesthetic-Nonaesthetic Distinction: The Aesthetic Value of Activist Art

Peggy Zeglin Brand

Select Bibliography to Part III

12 Has Her(oine's) Time Now Come? 
14 Leonardo da Vinci and Creative Female Nature

Mary D. Garrard

15 Mothers and Daughters: Ancient and Modern Myths

354

Ellen Handler Spitz

16 The Image of Women in Film: A Defense of a Paradigm

Noël Carroll

Select Bibliography to Part IV

392

V Feminism and Aesthetics: Directions for the Future

395

17 Analytic Aesthetics and Feminist Aesthetics: Neither/Nor?

399 Joanne B. Waugh

18 Reconciling Analytic and Feminist Philosophy and Aesthetics

Joseph Margolis

19 Why Feminism Doesn't Need an Aesthetic (And Why It Can't Ignore Aesthetics)

Rita Felski

20 The Role of Feminist Aesthetics in Feminist Theory Hilde Hein

Select Bibliography to Part V 


\section{List of Illustrations}

11. Joseph Wright of Derby, Experiment with an Air Pump. Tate Gallery, London. (photo: Bridgeman/Art Resource, New York)

51. Barbara Kruger, Untitled (Your Gaze Hits the Side of My Face), 1981. Courtesy Mary Boone Gallery, New York

61. Film still from Daughters of the Dust by Julie Dash. Courtesy Kino Intemational Corporation, New York

81. Film still from Surname Viet Given Name Nam by Trinh T. Minh-ha. Courtesy Trinh T. Minh-ha

32 Film still from Surname Viet Given Name Nam by Trinh T. Minh-ha. Courtesy Trinh T. Minh-ha

33. Film still from Surname Viet Given Name Nam by Trinh T. Minh-ha. Courtesy Trinh T. Minh-ha

41. Nancy Spero, Notes in Time on Women II (detail). Courtesy Josh Baer Gallery, New York

42 Nancy Spero, Notes in Time on Women II (detail). Courtesy Josh Baer Aallery, New York

101. Adrian Piper, Four Intruders Plus Alarm Systems. Collection Wexner Center for the Arts, The Ohio State University, Columbus; purchased in part with finds from The National Endowment for the Arts

312 Adrian Piper, Safe \#4. Courtesy John Weber Gallery, New York

Adrian Piper, Cornered, 1988. Courtesy John Weber Gallery, New Fitat (bhoto: Fred Scruton)

-12 Jenny Holzer, Untitled (The Last Room). Courtesy Barbara Gladstone cillery, New York

-3. Jenny Holzer, Untitled (The Child's Room). Courtesy Barbara GladIne Gallery, New York 
11.4. Barbara Kruger, Untitled (Your Body Is a Battleground), 1989. Courtesy Mary Boone Gallery, New York

12.1. Artemisia Gentileschi, Judith and Holofernes. Uffizi, Florence. (photo: Scala/Art Resource, New York)

14.1. Leonardo da Vinci, Gineura de' Benci. National Gallery of Art, Washington, D.C.; Ailsa Mellon Bruce Fund

14.2. Leonardo da Vinci, Lady with an Ermine. Czartoryski Museum, Kraków, Poland. (photo: Alinari/Art Resource, New York)

14.3. Leonardo da Vinci, "Anatomical Study." Royal College, Windsor, England. (photo: Alinari/Art Resource, New York)

14.4. Leonardo da Vinci, "A Fetus in the Womb." The Royal Collection (C) 1993 Her Majesty Queen Elizabeth II

14.5. Leonardo da Vinci, Virgin of the Rocks. Louvre, Paris. (photo: Alinari/ Art Resource, New York)

14.6. Leonardo da Vinci, "Star of Bethlehem." The Royal Collection (C) 1993 Her Majesty Queen Elizabeth II

14.7. Leonardo da Vinci, "Leda and the Swan." Museum Boymans-van Beuningen, Rotterdam

14.8. Leonardo da Vinci, The Virgin with the Child and Saint Anne. Louvre, Paris. (photo: Alinari/Art Resource, New York) 


\section{Foreword}

\section{Arthur C. Danto}

When feminism in its modern form arose in the late 1960 s, it did so as a prifical movement and as an intellectual one, and it was inevitable, in view of their profession, that academic women should be affected by both aspects at mee. Politically, feminism drew attention to, and sought to undermine, the asintionally grounded invidiousness of gender, in terms of the unequal Eseibution of rewards and of burdens across gender lines, and the suddenly macoeptable way in which the life-projects of individuals were systematically fuscatted or enhanced on the mere basis of sexual bimorphism and the biology if ueproduction. It seemed immediately unjust that women, merely because they were women, should be excluded from avenues of fulfillment to which In, merely because they were men, took themselves to have a natural right 1 acuess. These perceptions, and the imperatives of political action they = iled, were shared by academic feminists with their sisters elsewhere in ancity. And because what they were frustrated and oppressed by was yrinded in institutions that had to be changed if their lives were to be Anged, political feminism was almost certainly the most subversive of the Therationist movements of the period, largely because gender cuts across all te ther disabling divisions of society, and because once the grip of instituIn was weakened or broken in the case of women, everyone must in some w be affected. As for academic women themselves, they could not see it as ibed in the very nature of things that access, promotion, and reward in in institutions through which they had chosen to define their lives, should in av way turn upon gender, and the kinds of reasons colleges and universities we fir gender-based differentials seemed increasingly unacceptable and even mageous. These reasons in fact were, forms of myth that served the arpuse of keeping women "in their place"-and out of the places to which ther aspired.

The transperception of reasons as but disguised myths was facilitated by a menter of theoretical ideas that merged together with feminism in this period, 
and to which, in a great many of the traditional academic disciplines, feminism, as an intellectual movement, bound itself in a nearly chemical sense. This set of ideas, imported mainly from France, had the most monumental impact on the academic mentality, and it seemed in many ways to underwrite political feminism, and to explain how it was possible through academic labor-through a newly defined scholarship - to make a political and not merely an intellectual contribution. There was to begin with the detachment of texts from their authors in such a way as to render textual criticism an autonomous exercise, in which authorial intention was irrelevant and considerations of historical truth diminished in their relevance. Then there was the thought, advanced in a number of stunning writings by Michel Foucault, that all texts were to be understood as driven by political subtexts, and as serving entrenched powers, whatever the texts themselves might on their surface appear to be saying. And then there was the strategy of deconstruction, associated primarily with the thought of Jacques Derrida, which offered methods of reading texts in such a way as to penetrate to the covert agendas the texts promote. These intoxicating ideas were salted and seasoned with novel readings of Freud and of Marx, and attached themselves to certain abstract ideals of social revolution for which any disenfranchised body, not merely the traditional working class, might serve as the vehicle. These various strands of thought became constituted as "theory," and "theory" yielded up to those who accepted its authority the confidence that in the very act of textual deconstruction, they were advancing the political aims of feminism, as well as of the various other liberationist movements to which feminism was inevitably allied. Quite possibly they were right. Theory really did encourage the questioning of authority, and rested on the belief, almost a paraphrase of an ancient teaching of the Sophist Thrasymacus, that truth was what was in the interest of the ruling gender-or class, or race-to believe. And this relativism, allied with the anti-authoritarianism of theory, may very well have spread beyond the walls of the classroom, and helped feminists in their battles against the inequalities of everyday life.

Now the major enabling texts of theory came out of an intellectual tradition that was by no means shared by those academics in America upon whom theory had so immense an impact. All its main figures were trained in philosophy, and carried as part of their intellectual equipment the exacting knowledge of philosophy the French system demands of those who are to teach it. And it is fair to say that though Foucault's Les mots et les choses was a best-seller in France in the late 1960s, and though Derrida and Barthes were Parisian celebrities, their impact on the Continent was altogether different from that which their writings had in the text-oriented departments of Ameri- 
can colleges and universities, whose members had not been especially trained to deal with philosophical ideas. There is nothing, for example, in the traditional Isciplines of literary scholarship, or in the practices of close reading required of those who undertake advanced studies in literature, to equip them to handle texts that enter with the authority of philosophy, having been cast in the intoxicatingly obscure language that became the verbal vestment of theory as a form of writing. There were, so to speak, no defenses against it, with the result that the division between those who came of academic age in the pretheory period, and those whose education came from the texts of theory, was all but total. The originating texts of political as well as of intellectual feminism, greeminently Simone de Beauvoir's Le deuxième sexe, could have been easily assimilated to pre-theory academic minds, and indeed have been used to support political action of the direct sort, agitating for equal opportunities and If rmative action, and the dismantling of barriers to women's aspirations. It was the bonding of feminism to theory that made academic work seem like political work, so that reading Jane Austen as subversive was itself an act of subversion in the larger struggle of the sex. In academic departments other flan those that were text-driven, in science and in law and in engineering, political feminism made inroads on its own, without attaching itself to a body If texts understood as transformative of the disciplines. To be sure, the term fleconstruction," and something of its spirit, caught on, in part perhaps, hecause it harmonized with the spirit of the times. And some of the tenets of fineory were certainly invoked by scholars outside the textual disciplines. But it was these disciplines, mainly, that sustained the impact and underwent the zreatest transformation through internalizing theory's main attitudes and ideas. was primarily the central humanistic disciplines of literature and the arts where the impact was felt. And it has been, by and large, the text-driven asciplines that have tended to make the news that has elicited shrieks from fie conservative press, with proposals for the revision of the canon, and the sistence upon what the media refer to as political correctness.

Philosophers very early in the movement committed themselves to political eninism, and indeed some of the original feminist theorizing was done by Eilinsophers, almost all of whom were women. But theorizing, in their case, ail relatively little to do with theory, as this evolved in the humanities and to lesser extent in the social sciences. Philosophers, however strong their credentials, have by and large been cool to the claims of theory. ng in professional philosophical education rendered this discipline an atinspitable site for the novel strains of thought before which, for example, terature departments crumpled. In part this was a matter of the language: 
Anglo-American philosophy has aspired to a certain ideal of clarity, in which terms are defined with almost painful exactitude, and theses formulated with a nearly logical precision. And in part the traditional training in logic and in logical analysis has fortified philosophers against theory's almost systematic excesses. And while there is beyond question a body of historical texts all philosophers are required to be familiar with, these are hardly canonical in any damaging sense of the term: rather, part of philosophical education consists in criticizing these texts, in finding logical gaps and inferential flaws. The "canonical" texts of philosophy constitute a kind of gymnasium for the development of philosophical muscles, rather than a repository of disenabling truths. Beyond question the traditional philosophers had unenlightened things to say about women. But it would be difficult to see the philosophies, under deconstruction, as merely devices for enhancing the status of men. To teach them that way would dissolve their value in the philosophical curriculum. So philosophers today have a kind of continuity with their tradition quite different from what is sought in departments of theory. And this continuity in part is finally because philosophers do not merely do scholarship on the texts of philosophy. They are expected to do philosophy themselves. Poets, similarly, might have a very different relationship to the canons of literature than literary scholars do. Within the humanistic division, philosophy stands rather apart.

Certain themes, endemic to theory, are naturally going to be resisted by philosophers, however feminist. The topic of intention, authorial or otherwise, has for example been canvased since the early 1950s, with the publication of Wittgenstein's Philosophical Investigations, and the subsequent appearance of Elizabeth Anscombe's brilliant Intention. It is widely accepted by philosophers that there is some connection, not readily analyzed, between action and intention, and that this connection implies something for the philosophy of mind. At the very least, aware of the systematic embedding of intention with a large complex of concepts, philosophers would be circumspect in cutting intention out of consideration in the analysis of action. There are, as Anscombe was among the first to demonstrate, descriptions of actions under which they are not intentional-descriptions under which, as she would say, the question of reasons does not arise. But the central descriptions are those that connect action and intention together, and it is far from plain that the other descriptions have the importance for literature required by theory. Inevitably, texts can be described in ways having nothing to do with intentions, nor, accordingly, with the author's knowledge of what was being done and the reasons for doing it. But the descriptions under which texts are intentional may also be the ones under which they are literature. 
Similarly, relativism is not simply something to be accepted flatly. Not even Richard Rorty, who has been the philosopher theorists find most congenial, has denied that there are facts or that facts are real, only that truth is not something independent of human beings. By this, however, he means something not quite so exciting as it sounds: he means that "truth" is a property of sentences, and only human beings make sentences. But it hardly follows that in making sentences that are true, they somehow make them true; that is sumething that happens from the direction of the world. The issues of truth are thus left sufficiently intact that the further issue of relativism is not fireclosed. Relativism, like skepticism, is a constant topic of philosophical debate, but hardly a tenet of philosophical dogma, and in contrast with theory, pililosophers are not ready to throw truth overboard as a condition for ineration. Philosophical criticism is rarely deconstructive in tone or in effect. rather gives philosophers credit for wishing their theses to withstand titiques and to be able to overcome difficulties. The targets of criticism are rically treated as the critics' peers.

$\mathbb{Z}$ is in this spirit, in which for the most part feminist philosophers have zarticipated, that they have taken on questions felt to be of immediate interest w feminism: issues of language, of sexuality, of embodiment, of justice and zuality, and of values. A corpus of serious philosophical literature has been merging along these and other fronts, in which the methods of criticism and andysis have been powerful and exact instruments in the clarification of the sues that affect women's lives and thought-and the lives and thoughts of nen as well. There remain, of course, questions of a profound philosophical mine, left over when the issues of equality and justice are resolved, that mak to overlap the differences of gender. These have to do with the extent to with the self itself is gendered, and the degree to which gender may be said winflect our most profound relationships to and connections with one another Init with the world. There is an as yet underdeveloped feminist philosophy of cuviledge, of mind, of self, and of metaphysics. And it is hard not to speculate ane the possibility that gender might inflect everything, to the point where men and women might be said to live different worlds. Living different worlds = not entail-indeed, ought not to entail-discriminations in the common warit But it infuses the topic of the meaning of having a world in ways as yet anly understood.

testhetics is a very good area in which to extend feminist considerations, In pecause philosophers will be addressing the very objects- "textual anerts -addressed by theory. But also because works of art have a philonunical complexity that enables analysis of them to serve as models for the 
analysis of the larger complexes of lived life: issues of value, of subjectivity, of content, of meaning, and of embodiment that resonate throughout the domains of philosophical reflection. This volume is a pioneering work, and of the utmost importance not for feminism alone, but for aesthetics itself, which must benefit greatly through the ventilation of the topics feminists have made salient. Peg Brand and Carolyn Korsmeyer are exemplary philosophers and creative aestheticians, feminist thinkers, and intellectual crusaders. They have assembled in this sparkling collection some of the most instructive texts in the contemporary philosophy of art, demonstrating that feminism is neither a restricted topic nor solely of interest to a restricted audience. I am honored to have been asked to contribute this foreword. 


\section{Acknowledgments}

This project was first undertaken as a special issue of the Journal of Aesthetics and Art Criticism. For their help and encouragement during the time that the special issue was produced and thereafter as it developed into a book, we would like to thank the late John Fisher, editor of the Journal of Aesthetics and Int Criticism until 1988, Donald Crawford, editor of the journal from 1988 to 1983, Arthur C. Danto, president of the American Society for Aesthetics from 1989 to 1991, and Roger Shiner, secretary-treasurer of the American Society ir Aesthetics. We would also like to thank Laurie Shrage and Mary Bittner Wiseman for their helpful reviews of the manuscript. We are grateful to Nancy Spero for her generosity in allowing us to reproduce her artwork on the cover. 


\section{Introduction: Aesthetics and Its Traditions}

\section{Peggy Zeglin Brand and Carolyn Korsmeyer}

Any entry into the lists of scholarship takes its place among the received and developing ideas of its time. Feminist scholarship has a particular obligation to be reflective about this and to situate itself in the furiously changing history of challenges, questionings, and deconstructions of traditional systems of understanding that have taken place over the last quarter century. Approaches ID the study of women and of gender, to the differences represented by gender, sexual desires, and racial, ethnic, and national identities, have moved so very rapidly that it is difficult even for the diligent reader to keep informed. It the same time feminist methodologies, assumptions, and insights have teveloped unevenly, such that what is common presumption in one field of sudu may be perplexingly nonstandard even to feminists in another.

Some of the diversity of feminist scholarship proceeds from expectable Ifferences of opinions about subjects under investigation, such as the role of inilogy in the formation of gender or the independence of female cultural Iafitions, to mention just two long-standing themes of debate. At other times, tis diversity is entangled in one of the most notable reforms of research that fernism has fostered: the tremendous growth of scholarship that trades methodologies across disciplines. From the early days of their endeavors, feninist scholars have rightly perceived that barriers to thorough understanding of issues concerning women, sex, gender, patriarchy, and social diversity are constituted by traditions of inquiry themselves that proscribe what is Insidered legitimate research within recognized disciplinary frameworks. The turning of conventional academic divisions of study has dramatically enhanced the advancement of feminist scholarship.

Sometimes, however, what is proclaimed as interdisciplinary scholarship not mily rejects and supplants but also forgets or ignores what have been staple ssues of inquiry. Reflection on this phenomenon focuses attention on the Irplexities of traditions and their overthrow. The essays collected in Feminim and Tradition in Aesthetics shed light on the tenacity-sometimes 
tyrannical, sometimes useful_of various traditions in philosophies of the arts and theories of aesthetics. What cultural and intellectual frameworks inform our thinking about perception, beauty, art, and culture? And how have these influenced and been perpetuated by scholarly writing in aesthetics and philosophy of art? The essays collected herein are contributions by scholars in several disciplines, but they all address directly or implicitly aspects of the philosophical tradition. In what follows we speculate about the particular and idiosyncratic development of feminism in philosophical aesthetics; we seek to clarify its traditions and to indicate both how these traditions have resisted feminist inroads and how they afford important territory for feminist analyses.

In the 1990s there is already much well-known feminist scholarship in the arts, especially in literature and literary theory, art history and criticism, and film studies. The field of philosophy too has seen the development of a body of feminist thinking, particularly in the areas of philosophy of science and ethics. The philosophical subdiscipline of aesthetics, on the other hand, has only just begun to develop a feminist presence. One need only look at the syllabus for a standard introductory course or review the recommended reading list for a $\mathrm{Ph} . \mathrm{D}$. comprehensive exam in aesthetics to realize that the appearance of feminist scholarship is infrequent, if present at all. ${ }^{1}$ In light of twenty-five years of rich and stimulating feminist thought on the arts-feminist challenges applicable to the foundations of philosophical aesthetics-we ask, "Why, in the 1990s, are feminist writings still rare?"

The same question arises when one considers journal publication. The first special issue of an academic philosophy joumal in English devoted to feminism was The Monist 57, no. 1 (January 1973). Later the same year Philosophical Forum published another special issue. Shortly thereafter the journal Ethics began publishing feminist pieces, and even the Journal of Philosophy and other mainstream journals have had their occasional feminist pieces over the last decades. In short, while still a distinctly maverick voice, feminism has been heard in philosophy for quite some time.

It comes as a surprise to learn, therefore, that the Journal of Aesthetics and Art Criticism did not have any feminist presence whatsoever until 1990 with the publication of the special issue that became the basis for this collection (48, no. 4 [Fall 1990]). Conversely, the journal of feminist philosophy, Hypatia, saw few entries in aesthetics until the publication of its own special issue on the subject, also in 1990 (5, no. 2 [Summer 1990]). ${ }^{2}$ This phenomenon is even more perplexing if one bears in mind that the cognate disciplines of aesthetics, such as literary theory, art history, and film studies, have been among the academic vanguard of feminism since the early $1970 \mathrm{~s}$. This peculiar absence of 
feminism from the area of philosophy that-at first glance-looks to be among the most obvious for the entry of feminist scholarship deserves some comment. The following speculations hazard some answers as to why this has been the case.

Within the field of philosophy, aesthetics comprises a rather small area. The professional society devoted to the field is an interdisciplinary society, though the majority of its members are philosophers. ${ }^{3}$ Quite a few of these are also participants in other philosophical fields, notably philosophy of science, ethics, plilosophy of law, metaphysics, epistemology, and various areas in the history af philosophy. In short, philosophers who work in aesthetics are well connected to other areas of philosophy, as well as to related disciplines such as musicology, art history and criticism, and literature.

The converse, however, is not the case. While a philosopher interested in aesthetics is expected to be familiar with other areas of the field such as ethics, epistemology, logic, or metaphysics, practitioners in these latter fields may consider themselves quite well educated without knowing even a smattering of aesthetic theory. (Even in 1951, John Passmore lamented this fact, wondering whether [mere] philistinism was to blame. $)^{4}$ Aesthetics and feminist philosophy thus share an unenviable parallel: their scholars must know the work of others, though the others feel no reciprocal need to learn about either aesthetics or feminism. Therefore, to a degree the absence of feminist perspectives from aesthetics has been occasioned by bad intellectual habits.

If these disciplinary ruts were the only factors to consider, the matter would be merely of interest for sociology of knowledge, (or if one is feeling zuical, sociology of the academy). But there are also matters of considerable substance involved that concern basic presumptions about beauty, value, and Itt, in short, about the "tradition" to which this volume refers. Considering these factors requires an excursion into the issues that lie at the heart of the discipline.

\section{Traditions of Aesthetics}

In the longer version of its name, this field is known as "aesthetics and inilosophy of art." Aesthetic theories are often principally about art, but the wo component terms actually point in different if overlapping directions. "Aesfletics" is the more recent area of study, having developed in early modern European theory. It pertains to theories of perception that are interested in 
discovering the nature of the apprehension of beauty and other perceptual qualities of intrinsic value. The objects of aesthetic perception may or may not be works of art. As the philosophers of the eighteenth century whose founding interest is credited with the generation of the modern discipline observed, nature and mathematics could provide examples of aesthetic objects just as well as art. The chief goal of classic aesthetic theory is to investigate the bases for shared taste and perception of value. (A fuller discussion of these issues is presented in the preface to Part I.)

"Philosophy of art," like so many areas of philosophy, has been around since Plato. It concerns itself with the nature of creativity and of art objects, their value and social role, and their power to form character and convey knowledge. If beauty or other aesthetic qualities are held to be the presiding values for art, then theories of beauty become part of philosophy of art. And insofar as art theorists analyze perception, then the two areas of "aesthetics" and "philosophy of art" converge. (Because this is frequently the case in the modern period, the term "aesthetics" is often used as shorthand for the entire area of study.) Interest in perception and appreciation of works of art generates theories of the nature of interpretation and criticism and the ascription of meaning to cultural products. In this latter dimension aesthetics overlaps-in scope if not method-with critical studies of the arts.

In what is perhaps the most obvious sense, tradition for all these areas of aesthetics consists of so-called classics or canonical texts in the field and may be discovered by looking at required reading in university programs. ${ }^{5}$ While the content of instructional texts varies, there is considerable de facto agreement about what constitutes the staple readings of the field. Teaching anthologies typically include entries from Plato, Aristotle, Hume, and Kant in their historical sections, and often also include selections from writers such as Hegel, Schopenhauer, Nietzsche, Heidegger. These texts are generally familiar to scholars in other areas of philosophy and in the arts-related disciplines and are customarily acknowledged as of formative importance (and thus "canonical") for general intellectual history. When it comes to entries that deal with problems of contemporary aesthetics, the standard pieces shift character to much narrower disciplinary considerations. Some names remain widely familiar, especially those recent writers who are influential across disciplines such as Ricoeur, Foucault, or Derrida. But many others are new to all but those already practicing in aesthetics: names such as Bullough, Stolnitz, Sibley, Kennick, Weitz, Beardsley, that have been staple entries in aesthetics for decades and grow out of the ambient traditions of Anglo-American analytic philosophy. 
The "tradition" within and against which feminist perspectives are developed III the essays collected here is thus best considered in the plural. It is inpossible to discern clean categories within cultural history, but our purposes are served by distinguishing two aspects of tradition: the most familiar and zeneral tradition of Western philosophy that has shaped modern consciousness Wuot art in a wide sweep of disciplines; ${ }^{6}$ and the more recent philosophical Frecedents that have influenced aesthetics. ${ }^{7}$ Both of these connect with critical mantions regarding the interpretation and ascription of meaning to cultural Imaducts. Here we devote the most attention to the twentieth-century methits and approaches practiced in American philosophy; they form the principal actilrop for the variety of views that come to be united in this volume.

\section{Fistorical Traditions of Western Aesthetics}

greatest theoretical continuity within the Western tradition in aesthetics antends only since the eighteenth century, although roots of modern ideas go and have parallels as far back as classical antiquity. Any tradition that maces its roots as far back as Plato is going to contain considerable variety, ant to mention contrariety. The concept of art has not been a stable one; mileed, the idea of "fine art" is itself a product of early modern European mellectual history. ${ }^{8}$ But even shearing off the older history of philosophy of IIt, there have been so many varieties of theory in the last several hundred pears that even the modem traditions contain irreconcilable theories of art and athetic value. Some of their differences are signaled by the several "isms" If the field, such as the formalisms of Kant, Bell, and Hanslick; the idealisms If Hegel, Schopenhauer, and Croce; the expressionisms of Collingwood, nilstoy, and Kandinsky. These categories are not exhaustive, their terms of serription are not always univocal, and their memberships overlap and shift, Fending upon the aspect of art or theory under attention. Moreover, while In some respects the frequent entry of a thinker in a teaching text indicates an Irpurtance credited to his (or occasionally her) theory, ${ }^{9}$ some of their voices are entered as oddities or examples of extremist views and have not had the me influence over theory formation as the weight of their names would mugest. (Such is the case with Tolstoy and Dewey, for example, both of whin depart from the conventional assignment of high importance to the fine Ints and recommend an overthrow of traditional aesthetic values. $)^{10}$

Even among those who have exerted long influence over the formation of

ferry, there is considerable disagreement on such questions as the essential mine of art, the nature of creativity, and the character of the experience of 
beauty and other aesthetic values. Generalization, therefore, must proceed cautiously. Bearing these caveats in mind, we may yet step back and notice that the vast majority of these theories share two presumptions. They capture not only aspects of philosophical theories of art and aesthetics, but also the ideas about art that hold sway in the popular imagination and are thus broadly influential over the ways we thought and still think about the place of art in our lives.

First of all, it is rarely questioned that art's value transcends cultural differences and is a source of timeless and everlasting value. This ideal lies behind many popular cultural establishments, such as the notion that museums and libraries are important public institutions that guard the culture of the past for present and future generations. It subtends appeals to the value of liberal education in the humanities. And statements manifesting this value are present in theories that are otherwise vastly different. One could hardly find more divergent philosophical sensibilities than those of Hume and Heidegger, yet Hume observes that "The same Homer, who pleased at Athens and Rome two thousand years ago, is still admired at Paris and at London. All the changes of climate, government, religion, and language, have not been able to obscure his glory." 11 And Heidegger credits the timelessness of great art as providing a glimpse of Truth (the "unconcealedness of being"). ${ }^{12}$ Any created object of such a character must be the product of an unusual sensibility, and thus the artist who is capable of providing us with Art is often credited with Genius. Kant called genius the talent that "gives the rule to art," and Schopenhauer places art and the artist in fully reverent terms when he states that Art is the work of genius, which "repeats the eternal Ideas apprehended through pure contemplation, the essential and abiding element in all the phenomena of the world."13

Several of the authors of these scattered references express certain ideas of European Romanticism, though in their views about the special insight of the artist and the lasting value of art they echo ideas both more ancient and more modern. That theorists who differ on so many points should agree on the universal value of art indicates the depth of this presumption about the nature and character of art. Of course, that a vast array of thinkers should credit art with lasting importance is hardly surprising and not on the face of it particularly sinister. However, the collateral ideas that are invoked to explain the timeless value of art are ones that have come in for sharp critique from feminists. The brief quotes above indicate, for example, that the value of art is linked with the special mind of artists, and thus these theories give rise to a picture of the artistic Genius, a figure deeply inflected with masculine proper- ties both historically and conceptually. ${ }^{14}$ (Several of the essays in this volume continue discussion of the links between the concept of genius, the value of art, and the corollary evaluation of art by women; see Chapters 4,12 , and 13. )

There is a second common presumption underlying the broad sweep of intellectual history that constitutes this tradition. This pertains to the nature of appreciation of art and stipulates the state of mind that characterizes the apprehension of beauty, sublimity, and artistic greatness. It is held that the itate of aesthetic contemplation is a principal instance of intrinsic value; it takes one out of one's own self-concerns and peculiarities and into a state of mind that may be shared by any other human being. Thus it affords an escape from the individual ego and unites all who experience it in a common uppreciation, transhistorical and transcultural.

This assumption is less widespread in the history of philosophy and art lieory than is the former, but it is very strong in theory from the eighteenth century well into our own time. Perhaps it finds its purest expression in Kant's "Analytic of the Beautiful," where free beauty is characterized as disinterested ileasure taken in representation. Or in Schopenhauer's articulation of aesthetic iltention as a will-less state where the sense of self is lost and one is no longer lound by time and place. It finds its way into artwriting in Clive Bell's description of the appreciation of "significant form." In less extreme forms we find a host of views that typify aesthetic contemplation as a state of mind that diatances the perceiver from ordinary, mundane aspects of life. ${ }^{15}$ And the very lerm "aesthetic" qualities, referring to the presentational qualities of an object yjart from its instrumental, economic, or political characteristics, represents intinuation of the idea that aesthetic value occupies its own domain, separable firm aspects of practical life. ${ }^{16}$

Hoth these tenets about art and aesthetic value rely on a presumption that in inder fire from several directions at the present time: namely, that art and withetic attention are both in some sense universal. By "universal" it is unierted that art and aesthetic value possess at least ideally the same value fiif everyone, that they bind people together in experience. These two broad iniese have been challenged repeatedly in the latter part of this century, both iv feminists and postmodernists, and earlier by followers of Wittgenstein. hisimodernism's challenge is especially acute on the issue of the universality if aesthetic appreciation. It questions the notion of common subjectivity and iniee undermines what is strongest about theories that delimit a distinct area (if aesthetic consciousness: their demonstration of a common human faculty hiat binds all together and permits transcendence of cultural barriers.

feminists, especially those who study critical disciplines such as literary and 
film theory, have developed critiques of the broad Western tradition that are by now becoming familiar: that the universal subject is historically situated (masculine, patriarchal, imperialistic); and that the concept of fine or high art, along with the notion of artistic genius, is exclusionary both historically and conceptually. Several of the essays in this volume advance such critiques of modern European philosophical aesthetics, especially those in Part I. The essays in Part II continue feminist critiques of theories of aesthetic appreciation by considering the alternative theories of the gaze as illuminating modes of understanding the apprehension of visual art. (This challenge is discussed more fully in the preface to Part II.)

It is less well known that the history of analytic aesthetics has contained parallel objections to systematic theories of the arts and of aesthetic appreciation-objections that, while not feminist in character, provide more congenial company for feminist thinking than is ordinarily expected in philosophy. While at present many feminists regard analytic philosophy as a stultifying predecessor and look to European philosophy and its psychoanalytic cousins for the richer theoretical tools by which to understand gender, culture, and historical contingency, the early analytic turn was reacting to certain concerns that feminists share, notably skepticism about essentialism. The recent history of aesthetics and philosophy of art in this tradition is the subject we turn to next. The character and history of analytic aesthetics helps further to explain the late arrival of feminism to the scene.

\section{Analytic Aesthetics}

In certain respects philosophers of the analytic school continued the older traditions of aesthetics. For example, the tenet that aesthetic value and aesthetic qualities require definition in contrast to moral and practical properties remained strong in this school of thought. Thus continuity with the eighteenth-century theories of taste mentioned above is especially evident. ${ }^{17}$ But in other dramatic respects analytic philosophy broke radically with its precursor traditions, particularly those speculative philosophies of the nineteenth and early twentieth centuries that offered systematic theories of art embedded in metaphysical constructs. Hegelian and post-Hegelian idealist theories such as those of Benedetto Croce came under fire, although the general complaint eventually was directed to any aesthetic theory that attempted a systematic, essentialist definition of art.

Thus in the 1940s and 1950s, philosophers developed their own idiosyncratic sense of "tradition" in which "tradition" came to mean "pre-analytic," that is, works by authors predating Bertrand Russell, G. E. Moore, and others writing in the early years of this century who turned away from the speculative Idealist aystems that at the time were models of philosophical methodology. In terms of aesthetics, this notion of tradition congealed in mid-century with the hindsight of theorists heavily influenced by Wittgenstein, who were dissatisfied with the essentialism, romanticism, idealism, and what they perceived to be the endemic vagueness of their predecessors. Thus in 1958 William E. Kennick began his essay "Does Traditional Aesthetics Rest On a Mistake?" by stipulating, in no uncertain terms, what he meant by "traditional aesthetics": "By 'traditional aesthetics' I mean that familiar philosophical discipline which concerns itself with trying to answer such questions as the following: What is Art? What is Beauty? What is the Aesthetic Experience? What is the Creative Act? What are the criteria of Aesthetic Judgment and Taste? What is the finction of Criticism?"18

In 1948 W. B. Gallie had laid out "The Function of Philosophical Aesthetics" in an attack on the essentialist doctrines of Croce and Collingwood. He not inly called for an "informed skepticism" about all generalities concerning art, lie also turned an analytic eye to art-critical literature, urging careful rewriting of obscure and logically faulty criticism, pegging Wordsworth as his prime example. ${ }^{19}$ That same year, Arnold Isenberg delivered an address to the American Society for Aesthetics, later published under the title, "Critical Communication," in which he called for a similar redirection of energies. ${ }^{20} \mathrm{In}$ iii very title, John Passmore's "The Dreariness of Aesthetics" (1951) could not have been clearer in expressing the growing sentiment to abandon all work iii definitions of art, beauty, aesthetic experience, and the underlying princijee common to all "good" works of art. Five years later Morris Weitz jublished "The Role of Theory in Aesthetics," in which he argued against "any aliempt to state the defining properties of art," sounding the death knell iif "traditional" theory: "theory-in the requisite classical sense-is never firthicoming in aesthetics," he proclaimed. ${ }^{21}$

Thus the period during and just after World War II witnessed a prolific number of writings in analytic aesthetics, coinciding with the shift of the center of the artworld from Paris to New York, the rise of abstract expressionism with its attendant critic-devotees, and, interestingly enough, the formation and linowth of the fledging interdisciplinary group, the American Society for Aesthetics. Writing decades later, Richard Shusterman reconstructed the way ilitosophers must have felt at the time, namely, that analytic aesthetics came along just in time to "clarify" the "murky confusion" of the tradition. ${ }^{22}$ According to Shusterman, analytic aesthetics recommended a threefold assault 
upon tradition - anti-essentialism, metacriticism (seeking to clarify art criticism), and adoption of the paradigmatic methodology of scientific inquiry. One would surmise that this promoted some antagonism between philosophers who saw aesthetics as metacriticism and critics who saw no need or use for philosophers. As aestheticians invaded the domain of criticism, offering to "rewrite" critical copy they found faulty and obscure, it comes as no surprise to find, at least within the publications of the ASA's journal, that the number of nonphilosophers' contributions consistently diminished throughout its fiftyyear history. ${ }^{23}$ It is evident that the feminist scholarship that emerged from disciplines such as art history and literary theory in the early 1970s would not be welcomed by this particular legacy of the analytic tradition.

And yet, ironically, the impetus behind the initial feminist critiques of art history in the 1970s shares a certain orientation with analytic aesthetics of mid-century, specifically its skepticism about the univocity of "art" and its call to examine closely the way critical language actually functions, rather than to rely on hortatory prescriptions about how great art ought to be enjoyed. Linda Nochlin's ground-breaking essay of 1971, "Why Have There Been No Great Women Artists?" launched an entire movement centered on women's involvement in the arts. $^{24}$ In her review of the systematic exclusion of female artists from teaching studios and other realms of art instruction, Nochlin also suggested that because of its history, the traditional idea of fine art (and attendant concepts such as genius) may continue to overlook the creative products customarily undertaken by women.

Such analyses of the concept of art also contributed to the early questioning of the "canon" and of the standards that have chosen its membership. Feminist scholarship has unearthed women artists, writers, and musicians of the past that were oftentimes well known, amply commissioned, and self-supporting in their day but were subsequently omitted from the canon of "greats" in the written histories of art. ${ }^{25}$ These studies prompted skepticism about the "canon" of great art, leading feminists in the direction of more theoretical and abstract pursuits such as deconstructive analyses of the underlying assumptions of critical standards. A "new art history" was taking hold, emphasizing the "work of art itself as a piece of history" as opposed to the traditional focus on "the development and achievement of period styles, the history or sequence of works." 26

In their studies of the language of art history and criticism, feminist scholars began to explore the concepts of "greatness" and "genius" and why women never succeeded in acquiring either accolade. As with earlier anti-essentialism, definitions of "art" were rejected. To feminists, they were seen as limiting and oppressive: privileging "high" art over low, "fine" art over craft, men's art over women's. Early on, enthusiasm ran high that something like a female nature was discernible and that a woman's art or a feminine sensibility could be discovered. ${ }^{27}$ It was overtumed by another strain of anti-essentialism that focused not only on gender differences but differences within gender of nationality, race, class. The entire foundation of interpretation and evaluation came undone as feminists, in rejecting the conventional meanings assigned canonical works and texts, also questioned the obviousness of the intrinsic merits of Great Art. Thus, the first collection of feminist art-historical essays, Feminism and Art History: Questioning the Litany, sought to distinguish itself from catalogues and monographs by examining "Western art history and the extent to which it has been distorted, in every major period, by sexual bias." 28 Similarly, Rozsika Parker and Griselda Pollock's ground-breaking work, Old Mistresses: Women, Art and Ideology sought to establish strategies to subvert and collapse stereotypes of women and their art by means of analyzing women's historical and ideological position within the world of art production. ${ }^{29}$ Over less than twenty years, feminist critiques have broadened in scope to combine historical reclamation, linguistic analysis, sociological explanation, and philosophical questioning of the underlying assumptions of the traditions of a variety of fields. ${ }^{30}$

While analytic aesthetics and feminist art history share a disposition to criticize the staple concepts of theories of art, it is still the differences between these movements that are the most striking. Sharing as they may a skeptical and particularist method, they diverge profoundly in content and in the scope of questions considered important to pursue. Subjects mentioning women and gender have been very difficult to insert into analytic philosophy generally, for the simple reason that no such topics were considered "philosophical." Some portion of the philosophical literature of the twentieth century is mindful of the nature of philosophy itself, taking pains to distinguish this field from psychology, sociology, or criticism. Part of the early resistance of analytic philosophy to the advent of feminist perspectives in scholarship stemmed from the belief that subjects that specify gender digress into another discipline, one that deals in empirical data but not the abstract theorizing that marks philosophy. For similar reasons, philosophers have avoided the political dimension of art. Hence part of the charge of feminism to analytic aesthetics is that philosophers still neglect the cultural and historical context of a work of art, such as the gender, race, class, and particular historical situation of the artist and her audience. Happily, the era of erecting strict boundaries for legitimate philosophical inquiry has largely passed, although its lingering influence accounts in 
part for the late entry of feminism into philosophical aesthetics. One can see a general discomfort regarding the limitations of scope of legitimate subject matter in recent reflections on the state of aesthetics in general and analytic aesthetics in particular. ${ }^{31}$

It is important to note that despite early enthusiasms to the contrary, not all philosophers found (or continue to find) analytic aesthetics to be a panacea for critical and philosophical ills. The cyclical process of criticizing and replacing old ways with the new was bound to result in the new itself becoming old. Thus philosophers critical of analytic aesthetics have adopted yet another, more inclusive meaning of the term "tradition." For the authors in the 1980s and 1990s, "tradition" not only includes the pre-analytic, speculative, and Idealist traditions, but also the body of analytic writings that dominated American philosophy mid-century.

The 1987 special issue of the Journal of Aesthetics and Art Criticism provides a retrospective look at the past decades of analytic aesthetics and speculations about its future. The mood it conveys is quite different from that of earlier years. Somber and speculative, it brings to light the concerns and rumblings building for several years over the influx of "other" modes of thinking in aesthetics, including the deconstructive styles of poststructuralism. Shusterman's introduction to the issue suggests that the future of analytic aesthetics is in doubt. As he puts it, the pressing issue is whether analytic aesthetics "needs an epitaph and (if it does) what should there be inscribed." 32 For some, the prospect of a postanalytic period (or worse yet, as Shusterman adds, a postphilosophical era) was sobering. For others, it was a welcome relief.

Anita Silvers asks the question this way: "Has Analysis Made Aesthetics Clear?" 33 Referring to the original goals of Arnold Isenberg, W. B. Gallie, and Margaret Macdonald, she concludes that analytic aesthetics actually added to the dreariness cited by Passmore in 1951 by calling for too strict a revision of art-critical language and argument forms at the expense of fulfilling their function: to make art more accessible and appreciated. Praising the more recent theories of Arthur Danto and Nelson Goodman (discussed below) as exemplars of Isenberg's recommendation "to integrate insightful commentary on art with rigorous philosophical argument," Silvers encourages a return to a discussion of art objects to ground and advance theoretical concerns. To Marx Wartofsky, analytic aesthetics only succumbed to dreariness when put in a "derivative" or "dependent posture," that is, of relying upon previous analysis for its raison d'être. His suggestion for infusing new life into the profession? Again, a return to the arts. ${ }^{34}$ What emerges from a number of authors is a sense that, in spite of intentions to attend more closely to actual works of art, analytic philosophers became isolated from the world of art and too selfabsorbed. (Roger Scruton, writing elsewhere, castigated aesthetics and philosophy in general, for retreating from artistic and literary culture, thereby abandoning it to the deconstructionists, and for adopting "the rigour-or rigor mortis-of semantic analysis." $)^{35}$

These authors record what Joseph Margolis calls "a kind of increasing suicidal neglect of the leading themes of cultural life," in spite of attempts by Arthur Danto and George Dickie to come to grips with the most provocative art of the twentieth century. ${ }^{36}$ Margolis has resisted the insularity of analytic aesthetics and suggests that the field can be resuscitated by accommodating all forms of critique, including Continental philosophy ("the historicist, hermeneutic, the preformational, structuralist and poststructuralist, the deconstructive, the genealogical, the praxical") and, specifically, feminism. ${ }^{37}$

Analytic approaches in aesthetics as described earlier and as the subject of this recent critical reflection saw their glory days in mid-century. In the 1960s aesthetics as practiced by analytic philosophers began to shift its orientation, at first gradually, then with increasing rapidity in the 1970s and 1980s. A noteworthy catalyst for this shift was the publication in 1965 of Nelson Goodman's Languages of Art. Goodman's previous work had been in metaphysics and philosophy of science, not aesthetics, and thus perhaps he felt more carefree with regard to the standard questions framing philosophy of art. His book bypassed issues of the nature of artworks and the character of the aesthetic, concentrating rather on symbol systems and the logical relations between different kinds of symbols and their objects. The previous year Arthur Danto published his influential essay "The Artworld," which argued against anti-essentialism and made legitimate again the exploration of the concept of art, replacing appeal to shared exhibited properties with relational properties situating artworks in cultural space and historical contexts. ${ }^{38}$ These ideas were further developed in The Transfiguration of the Commonplace (1981) and put into practice in Danto's art criticism. ${ }^{39}$ (Interestingly, this attention to symbols and to the relation of art to cultural contexts returns philosophy of art to its earliest problematic: the nature of mimesis. ${ }^{40}$

Goodman, Danto, and Margolis are but three of the major theorists who have fostered a change in aesthetic theorizing toward the historical contexts in which art takes form and achieves meaning. The current approaches to art and culture that typify present-day aesthetics are potentially rich for the development of feminist perspectives, for they place attention to cultural frameworks and their historical contingencies at the heart of philosophies of art. They dispense once and for all with the stubborn analytic claim that descriptors of 
social diversity derail philosophy into sociology. Therefore in a general way they are ineluctably (if not explicitly) politicized; as such they invite close inspection of the practices of institutions, especially their selection practices (whether patriarchal, class-based, colonialist).

In spite of this potential, however, attention to feminism or to gender is still not a significant presence in contextualist theories, even those that are otherwise iconoclastic about time-honored dichotomies such as the distinction between fine art and craft and "high" or "low" art. Perhaps the cold hand of the earlier legacies of philosophy still touches the discipline. Then, too, the new contextualist theories, in returning to classic questions about the distinguishing attributes of art, have been more interested in discovering why and how an object becomes a recognized artwork than in investigating what is not so recognized or what has been shouldered out of the limelight. The task remains for feminists to cultivate this project as they explore useful intersections between the advances made in (post-)analytic aesthetics and recent strategies of feminist theorizing.

\section{Interpretive Frameworks: The Ascription of Meaning to Art}

The self-reflective nature of recent analytical writing, such as that of Danto and Margolis, opens the door to exploring issues of gender and other sociopolitical aspects of art by highlighting the importance of the historical context of a work of art. Concurrent with this broadening of outlook in philosophy, feminism has already undergone several phases of self-reflection. A constant reassessment of artistic practices and interpretive approaches has fostered attention to what it means to analyze art in its fullest, broadest context. Although at times its character and tone might appear unrecognizable to those unschooled in its ways, analysis has always been part of feminist theorizing. ${ }^{41}$ Its central purpose is a moving away from the entrenched, dominant, and limiting tenets of "patriarchal aesthetics," which permits only some predetermined aspects of a work to be considered contextually relevant, toward a strategy of less constrained attention to a variety of facets, determined by the historical moment and particular character of an experience. ${ }^{42}$ Thus feminism and philosophy share an interest in the question of how the nature and boundaries of art are shaped by context.

Thus far we have discussed matters that pertain to the philosophical traditions of aesthetics, especially theories of the nature of art and of aesthetic perception. We have said little directly regarding related disciplines and theories of interpretation or viewer and reader response; thus we have not engaged the literature of theoretical criticism that has had such an influential feminist presence. Here we shall not even attempt to summarize this massive field; we refer readers to the bibliographies at the end of each of the five parts of the text. We shall, however, briefly discuss two issues that not only bear on the common question of defining the parameters of contextual relevance, but also confront staple elements of the philosophic tradition discussed above: the philosophy of mind employed by theories of the viewing subject, and the methods by which aesthetically relevant properties of art are to be determined.

Classic theories of aesthetic perception that were developed in eighteenthcentury philosophy were based upon a certain view of perception and of the mind. They presumed that the human mind should be considered in its basic components as a kind of generic subjectivity, operating similarly in all fully functioning rational creatures. These philosophies-well aware that judgments of taste (assessments of artistic quality and value) often vary noticeably by individual, historical period, and culture-were bent upon articulating the bases for aesthetic pleasures that transcended these "incidental" differences. This articulation was made possible by the assumption that pure aesthetic pleasure (often taken in formal relations or nature, objects of attention less reliant on cultural fluency than complex works of art) is a basic capacity of the human perceptive faculty. And this assumption is only possible if one first assumes that beneath their contingent differences all minds are essentially similar.

This model of the mind and of conscious experience has not been noticeably useful to feminists, whose interests focus on understanding the development of gendered points of view and understanding the diverse positions of the masculine and the feminine in culture. Thus neither the generic consciousness of earlier European philosophy, nor its theoretical orientation to formal aesthetic pleasure has suited the aims of recent feminist theory. More complex models of consciousness have been needed, suited to understanding the subtle and devious pleasures of representation. One of the most fruitful models of mind available for this task has its roots in Freud's psychoanalytic theory and its Lacanian modifications. ${ }^{43}$ (Within the Anglo-American tradition, psychoanalysis has not been widely embraced by philosophers writing in aesthetics. ${ }^{44}$ Feminists have adapted psychoanalytic insights in order to formulate theories more sensitive to gender and social position than either Enlightenment philosophy or Anglo-American philosophy has provided. This body of scholarship has yielded not only schools of reading and interpretation, but also a theoretical tool that has been widely employed in feminist understandings of art: theories of the gaze. Supplanting older notions of aesthetic perception, theories of the 
gaze analyze the pleasure to be found in representation by bringing to light the consciousness of the culturally prescribed viewer: a male of dominant social standing. Theories that employ the notion of the male gaze are one manifestation of widespread suspicion of the older notion of a universal subject, and of assumptions of the transparency of the mind, such that one can know from introspection the nature of aesthetic pleasure. (In this volume, discussions of psychoanalytically informed feminism may be found in Chapters 5 and 6; modifications or challenges to psychoanalytic approaches are presented in Chapters 15 and 16.)

Psychoanalysis is not the only recent theoretical movement to challenge traditional approaches to the appreciation and interpretation of art. Indeed, the vigorous effort on the part of feminists to situate artworks in their historical context and to read their changing meaning for contemporary audiences confronts an old analytic question: What qualities actually "belong" to the work itself? In our discussion of the broad philosophical tradition, we noted two presumptions shared by most participant theorists: that the value of art is timeless and transhistorical, and that the apprehension of aesthetic qualities removes the perceiver from his or her particular and contingent situation. A certain approach to critical interpretation and evaluation of art is bound together with these two theses, namely, that whatever value art has, it possesses autonomously. The aesthetic qualities of art are thus available for appreciation without reliance on knowledge of anything outside the work of art itself. In an extreme form this view was enacted by the New Criticism of the 1940s and 1950s. Its most famous statement in aesthetics was made in 1946 with the publication of "The Intentional Fallacy" by Monroe Beardsley and W. K. Wimsatt, which objected to the relevance of what they called "nonaesthetic" historical and contextual data, that is, data external to a work of art. ${ }^{45}$ Critics of this view have hewn away at it for some time, but the question central to their claim - What are the parameters to legitimate artistic interpretation?-is as relevant as ever.

Indeed, feminist criticism and art history have given this question new life, as scholars reinterpret the historical record and the legacy of artworks and as they assess both the treatment of women in art and the type of art produced by women. (See Chapters 12-14.) Virtually all feminist interpretive strategies give rise to the philosophical question of whether and how the gender of artists-as well as their other socially marked identities - are to count as properties of works of art and to be recognized as aesthetically relevant. (See also Chapter 9 for a discussion of feminist frameworks as schemata for interpretation.) But the role such factors play in ascribing meaning to art is not always clear; hence the need for extending the dialogue between philosophy and feminist art theory.

Feminism and philosophy are fortunately situated at a moment of intersecting interests that provides opportunities for transdisciplinary scholarship on common theoretical questions. Though feminists are hesitant to prescribe any monolithic, unified feminist aesthetic, they are determined to maximize and extend discussions of the role of gender in cultural production. (Chapter 19 argues against an autonomous aesthetic while still emphasizing the aesthetic.) Some envision feminist theory relocated more centrally within aesthetic inquiry; others worry about the incompatibility of feminism with long-standing analytic and Continental philosophical concerns. (See Chapters 17, 18, and 20.) Others seek more linguistic analysis and the study of intertextuality, pursuing strategies that cope with texts the meanings of which are determined by context but the context of which can change without limits. ${ }^{46}$ Still others prefer a sociological approach, emphasizing the social history of the discipline of aesthetics and the ways it has influenced the production and reception of objects deemed art. ${ }^{47}$ Recalling Alpers's characterization of the "new art history" in 1977, which brought attention to the "work of art itself as a piece of history," these suggestive frameworks redirect concentration toward an emphasis on the actual practice of encountering and confronting art, in keeping with the reflective criticism of recent philosophical aesthetics.

Each of the parts that organize this volume is preceded by a short preface that reviews the issues the essays address, expanding upon the topics of "tradition" that we have introduced here. The majority of our contributors have their academic roots in philosophy; one is a psychoanalytic theorist, and others work in the critical disciplines of art, music, and literature. Two are both scholars and practicing artists. Adrian Piper, philosopher and graphic/conceptual artist, and Trinh T. Minh-ha, literary scholar, composer, and filmmaker, represent ways in which feminist perspectives on aesthetic value may be enacted in the practices of art. We hope that these multidisciplinary approaches will both advance the growing work of feminism in aesthetics and prompt writers in other fields to consider some of the issues as they are treated herein.

We have stressed here the departure from tradition fostered by feminist perspectives; in doing so we have focused on the ways these essays review the past. But it will be obvious that they equally well preview the future. We hope that the philosophical slant of this book will contribute to the development of transdisciplinary thinking about art theory, concepts relevant to aesthetics, 
and feminism. We urge more disciplinary dialogue among feminists in philosophy in order to link insights from other areas with philosophies of the arts. Topics in aesthetics can be usefully informed by recent feminist advances made in philosophy of science, epistemology, ethics, and political theory: for instance, challenges to traditional theories of rationality in which the disinterested, disembodied Cartesian knower is replaced by a conception of the knowing subject "as situated, as engaged and as a part of a community" parallel feminist deconstructions of aesthetic perception. ${ }^{48}$ Similarly, challenges to traditional moral theory's notion of an independent, impartial moral agent who is replaced by a model of moral thinking based on relationships, with moral actions arising out of responsibilities and affiliations rather than duties or rights, could be brought to bear on the aesthetic assessment of the moral and political value of art. Might this cast a different light on the traditionally valued Romantic notion of the independent (male) genius? How would the feminist notion of an "ethics of care" affect the interpretation and evaluation of woman's crafts, for example, quilts? political activist art? How does the evaluation of women's art mesh with traditional political theory, which bifurcates the public and private realms? How is the status of women in the worlds of art further complicated by issues of race, class, culture, and sexual identities? ${ }^{49}$ And more reflexively, how does philosophy enter into the web of determinants concerning how we think about art? The essays gathered here begin to investigate the traditions of aesthetics and to determine the power of theoretical frameworks themselves to invite or constrain recognition of artists and cultures.

\section{Notes}

1. Of the many existing anthologies recently published, only three contain entries on feminism: John W. Bender and H. Gene Blocker, eds., Contemporary Philosophy of Art: Readings in Analytic Aesthetics (New York: Prentice-Hall, 1993); Stephen David Ross, ed., Art and Its Significance, 2d ed. (Albany: State University of New York Press, 1987); and Patricia Werhane, ed. Philosophical Issues in Art (New York: Prentice-Hall, 1984). The selection of essays for teaching collections has come in for earlier criticism. In 1973 Mary Mothersill complained that "the same essays appear in each new anthology" (introduction, Aesthetics and the Theory of Criticism: Selected Essays of Amold Isenberg (Chicago: University of Chicago Press), xix-xx.

2. Feminist interest in the body and norms for female beauty have prompted steady attention in this journal. Hypatia, moreover, has published a number of articles devoted to or influenced by French feminism, including a special issue edited by Nancy Fraser and Sandra Bartky (3, no. 3 [Winter 1989]). This type of theory is particularly sensitive to style and to modes of presentation of ideas and thus is at least tangentially relevant to aesthetics even when the subject under discussion is something else.

3. On the occasion of its fiftieth anniversary, Lydia Goehr documents the membership of the American Society for Aesthetics and the authorship of articles in its main publication, the Journal of Aesthetics and Art Criticism: see "The Institutionalization of a Discipline: A Retrospective of The Journal of Aesthetics and Art Criticism and the American Society for Aesthetics, 1939-1992," $J A A C$ 51, no. 2 (Spring 1993). Members of the ASA numbered 957 in 1992 (as compared to approximately 7000 members of the American Philosophical Association). Overall, 46 percent of the articles in the JAAC written between 1941 and 1991 were by philosophers; however, between 1941 and 1951, 35 percent were written by philosophers whereas between 1981 and 1991, philosophers authored 70 percent.

4. John Passmore, "The Dreariness of Aesthetics," Mind 60 (1951). This essay is reprinted in William Elton, ed., Aesthetics and Language (Oxford: Basil Blackwell, 1954), and in Francis J. Coleman, ed., Aesthetics: Contemporary Studies in Aesthetics (New York: McGraw-Hill, 1968).

5. With the advent of the J. Paul Getty funding in the form of the DBAE (Discipline-Based Art Education), which includes the multiple disciplines of studio art, art criticism, art history and aesthetics, philosophical issues have been introduced into the $\mathrm{K}-12$ curriculum in certain areas of the country. The readings in aesthetics in those curricula replicate standard "canonical" texts, thereby educating future generations to be more philosophically astute in their discussions of art, though no broader in outlook than their predecessors.

6. There are cultural precedents in Asia, Africa, and elsewhere in which philosophies reflect the inseparability of the arts from other aspects of life, precedents that have provided models for nome feminist scholars. Renée Lorraine, whose essay "A History of Music" appears in this volume, is one such scholar. See also her "A Gynecentric Aesthetic," in Aesthetics in Feminist Perspective, ed. H. Hein and C. Korsmeyer (Bloomington: Indiana University Press, 1993). As a rule these non-Western traditions have not played much of a role in the United States either in aesthetics or in philosophy generally.

7. Both the long and the recent intellectual traditions have ignored consideration of sex and gender in their theorizing. But while feminism is beginning to establish an increasingly well known critique of the former, Anglo-American traditions have been largely neglected until very recently. More feminist work has been done on analytic epistemology and philosophy of science. For some specific treatments of this method, see Jane Duran, Toward a Feminist Epistemology (Savage, Md.: Rowman and Littlefield, 1991) and Lynn Hankinson Nelson, Who Knows: From Quine to Feminist Empiricism (Philadelphia: Temple University Press, 1990).

8. See Paul Osker Kristeller, "The Modern System of the Arts," Journal of the History of Ideas 12-13 (1951-52), widely reprinted; and L. Lipking, The Ordering of the Arts in EighteenthCentury England (Princeton: Princeton University Press, 1970) for discussions of the development of the idea of the fine arts in the early modern period.

9. There were several women active in the early days of analytic aesthetics, including Margaret Macdonald, Helen Knight, Katherine Gilbert (coauthor with Helmut Kuhn of $A$ History of Aesthetics [Bloomington: Indiana University Press, rev. ed. 1953]), and Isabel Creed Hungerland. Gilbert and Hungerland each served two-year terms as president of the ASA, in 1946 and 1965 respectively. The content of their scholarship did not deviate significantly from the general concerns of the male-dominated group. Probably the best-known book in aesthetics by a woman is Susanne Langer's Feeling and Form (1953).

10. Some feminists have found in pragmatism a neglected American tradition that is congenial in feminism. See the special issue of Hypatia, edited by Charlene Haddock Siegfried, devoted to feminism and pragmatism $(8$, no. 2 [Spring 1993]). A recent appreciation of Dewey also can be found in Richard Shusterman's Pragmatist Aesthetics (Oxford: Basil Blackwell, 1992).

11. David Hume, "Of the Standard of Taste" (1757), in Aesthetics: A Critical Anthology, ed. G. Dickie, R. Sclafani, and R. Roblin (New York: St. Martin's Press, 1977), 596. 
12. See "The Origin of the Work of Art," in Art and Its Significance, ed. Stephen David Ross (Albany: State University of New York Press, 2d ed., 1987).

13. Arthur Schopenhauer, The World As Will and Representation, 2 vols., trans. E. F. J. Payne (New York: Dover, 1969; first published 1859), 1:184.

14. See, for example, Christine Battersby, Gender and Genius (London: Women's Press; Bloomington: Indiana University Press, 1989); and Whitney Chadwick, Women, Art, and Society (London: Thames and Hudson, 1990).

15. See Kant, The Critique of Judgment (1790), especially the "First Moment of Beauty;" 15. See Kant, World as Will and Representation (1819); Clive Bell, Art (1914); and Edward Schopenhauer, The World as Will and Representation (1819); Clive Bell, Art (1914); and Edward
Bullough, "Psychical Distance' as a Factor in Art and an Aesthetic Principle" (1912), widely reprinted, including in Dickie, Sclafani, and Roblin, eds., Aesthetics: A Critical Anthology.

16. More recent theories of the aesthetic may be found in Jerome Stolnitz, Aesthetics and Philosophy of Art Criticism (Boston: Houghton Mifflin, 1960) and Frank Sibley, "Aesthetic Philosophy of Art Criticism (Boston: Houghton Miffin, 1960) and

17. This continuity is explored by Jerome Stolnitz, "On the Origins of Aesthetic Disinterestedness " Journal of Aesthetics and Art Criticism (Winter 1961), widely reprinted, including in Dickie, Sclafani, and Roblin, eds., Aesthetics: A Critical Anthology.

18. William E. Kennick, "Does Traditional Aesthetics Rest on a Mistake?" Mind 67 (1958), 18. William E. Kennick, "Does Traditional Aesthetics Rest on a Studies in Aesthetics (New York: McGraw-Hill, 1968), 411.

19. W. B. Gallie, "The Function of Philosophical Aesthetics," Mind 57 (1948), reprinted in Coleman, ed., Aesthetics.

20. Arnold Isenberg, "Critical Communication," Philosophical Review 58 (1949), widely reprinted. Isenberg also wrote an unpublished report to the Rockefeller Foundation in 1950 titled, "Analytical Philosophy and the Study of Art," only portions of which are published in Aesthetics and the Theory of Criticism: Selected Essays of Amold Isenberg (Chicago: University of Chicago Pr the 1973) A detailed account of Isenberg's work in its historical context is provided by Anita Silvers, "Letting the Sunshine In: Has Analysis Made Aesthetics Clear?" originally published in Journal of Aesthetics and Art Criticism 46 (1987) and reprinted in Bender and Blocker, eds., Contemporary Philosophy of Art.

21. Morris Weitz, "The Role of Theory in Aesthetics," Journal of Aesthetics and Art Criticism 15 (1956), widely reprinted.

22. See Richard Shusterman's introduction to Analytic Aesthetics (New York: Basil Blackwell, 1989), 1-19. A portion of these essays was originally published in a special issue of the Joumal of Aesthetics and Art Criticism 46 (1987).

23. Lydia Goehr charts these decreasing numbers (see note 3 above.) The speculation offered here is ours.

24. Linda Nochlin's essay originally appeared in Art News 69 (January 1971) and is reprinted in her Women, Art, and Power and Other Essays (New York: Harper and Row, 1988).

25. The show "Women Artists: 1550-1950" and its accompanying catalogue brought to light works by women that were attributed to male artists, forgotten in museum basements, and obscured by the preponderance of "masterpieces" that hogged the limelight. See Ann Sutherland obscured by the preponderance of "masterpieces" that hogged the limelight. See Ann Surther Harris and Linda Nochlin, Women Artists: 1550-1950 (Los Angeles: Los Angeles County Museum of Ar, 1

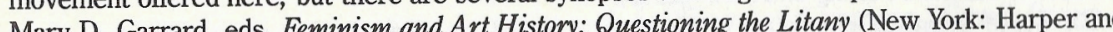
Mow, 1982); Thali Gouma-Peter "The Feminist Critique of Art allen History," Art Bulletin 69 (September 1987): 326-57; Toril Moi, Sexual/Textual Politics: Feminist Literary Theory (New York: Methuen, 1985 and several reprints); and Norma Broude and Mar D. Garrard, eds., The Expanding Discourse: Feminism and Art History (New York: HarperCollins, 1992). See also the bibliographies provided within each of the five parts of this volume.
26. Svetlana Alpers, "Is Art History?" Daedelus 106, no. 3 (Summer 1977).

27. A feminine aesthetic was under discussion in Germany in the early years of the women's movement. Essays from the late 1970s and early 1980s became available in translation in Gisela Ecker, ed., Feminist Aesthetics (Boston: Beacon, 1985).

28. Broude and Garrard, eds., Feminism and Art History, 1.

29. Rozsika Parker and Griselda Pollock, Old Mistresses: Women, Art, and Ideology (New York: Pantheon, 1981).

30. For an overview of this development in the history of visual arts, see Norma Broude and Mary D. Garrard's introduction to The Expanding Discourse: Feminism and Art History.

31. In addition to the special issue on analytic aesthetics mentioned above, two recent issues of the Journal of Aesthetics and Art Criticism provide reflection on the state of the discipline. See the fiftieth-year commemorative volume mentioned above, and the volume dedicated to "Philosophy and the Histories of the Arts" (51, no. 3 [Summer 1993]), ed. Donald W. Crawford. Other sources include Bender and Blocker's Contemporary Philosophy of Art, and the thorough and wellwritten Definitions of Art by Stephen Davies (Ithaca: Cornell University Press, 1991).

32. Shusterman, JAAC 46 (1987): 115. It is interesting to note that the first essay in this issue is a portion of Arnold Isenberg's "Analytical Philosophy and the Study of Art: A Report to the Rockefeller Foundation" (1950).

33. Silvers, "Letting the Sunshine In."

34. Marx Wartofsky, "The Liveliness of Aesthetics," Journal of Aesthetics and Art Criticism 46 (1987). Nicholas Wolterstorff concurs in "Philosophy of Art After Analysis and Romanticism" in the same issue.

35. Roger Scruton, "Modern Philosophy and the Neglect of Aesthetics," Times Literary Supplement (5 June 1987).

36. Joseph Margolis, "The Eclipse and Recovery of Analytic Aesthetics," in Shusterman, ed., Analytic Aesthetics. See also "Exorcising the Dreariness of Aesthetics," Joumal of Aesthetics and Art Criticism 51, no. 2 (Spring 1993): 133-40.

37. Margolis, "Eclipse and Recovery," 35-36. See also his essay in this volume.

38. See also George Dickie's institutional theory in Art and Aesthetics: An Institutional Analysis (Ithaca: Cornell University Press, 1974), and Joseph Margolis's theory of cultural emergence, Art and Philosophy (Brighton, Sussex: Harvester, 1980).

39. Arthur C. Danto, "The Artworld," Journal of Philosophy 61, no. 19 (1964); The Transfiguration of the Commonplace (Cambridge: Harvard University Press, 1981). In addition to his philosophical work, Danto writes a column on art for The Nation. Some of his collected essays on art may be found in Encounters and Reflections (New York: Farrar, Straus, and Giroux, 1990) and The State of the Art (New York: Prentice-Hall, 1987).

40. See, for example, Kendall Walton, Mimesis and Make-Believe (Cambridge: Harvard University Press, 1990).

41. French feminist writers like Hélène Cixous, Luce Irigaray, and Julia Kristeva are sometimes considered inaccessible and as a result have been widely ignored by American philosophers. This is true in spite of works such as Irigaray's analysis of the history of Western philosophy in Speculum de l'autre Femme (Speculum of the Other Woman) (Paris: Minuit, 1977).

42. Toril Moi presents a cogent overview of both the Anglo-American and French strands of feminist literary theory and how they relate to "patriarchal aesthetics" in Sexual/Textual Politics. See also K. K. Ruthven, Feminist Literary Studies: An Introduction (Cambridge: Cambridge University Press, 1984) and Rita Felski, Beyond Feminist Aesthetics (Cambridge: Harvard University Press, 1989).

43. Freud and Lacan have influenced both French feminism and feminist critics such as Jane Gallop, Shoshana Felman, and Gayatri Spivak. An overview of French thinkers can be found in Elaine Marks and Isabelle de Courtivron, eds., New French Feminisms (Brighton, Sussex: 
Harvester, 1980). The influence of these on American theory is discussed in Hester Eisenstein and Alice Jardine, eds., The Future of Difference (Boston: G. K. Hall, 1980).

French philosophy and feminism is discussed in Jeffner Allen and Iris Marion Young, eds., The Thinking Muse: Feminism and Modern French Philosophy (Bloomington: Indiana University Press, 1989).

44. A noteworthy exception is Richard Wollheim; see his Painting as an Art (Princeton: Princeton University Press, 1987).

45. W. K. Wimsatt, Jr., and Monroe C. Beardsley, "The Intentional Fallacy," in The Verbal Icon (Lexington: University of Kentucky Press, 1954), reprinted in Joseph Margolis, Philosophy Looks at the Arts, 3d ed. (Philadelphia: Temple University Press, 1987).

46. This is Toril Moi's recommendation in Sexual/Textual Politics, as influenced by Kristeva and Derrida.

47. See Janet Wolff, Aesthetics and the Sociology of Art, 2d ed. (Ann Arbor: University of Michigan Press, 1993). This work invites comparison to Dickie's institutional analysis of art.

48. See Nancy Tuana's comments on the challenge of feminism for philosophy in Woman and the History of Philosophy (New York: Paragon House, 1992).

49. Elizabeth V. Spelman, Inessential Woman: Problems of Exclusion in Feminist Thought (Boston: Beacon, 1988).

\author{
I \\ Gender and \\ Eighteenth-Century \\ Aesthetic Theory: \\ New Readings of \\ Traditional Theories of \\ Taste, Beauty, \\ and Sublimity
}

